\title{
EFEKTIFITAS PEMBERIAN EKSTRA PUTIH TELUR TERHADAP PENINGKATAN KADAR ALBUMIN DAN IL-6 PADA PASIEN TUBERKULOSIS DENGAN HIPOALBUMIN
}

\author{
Agus Prastowo ${ }^{1}$, Wiryatun Lestariana ${ }^{2}$, Siti Nurdjanah ${ }^{3}$, Retno Sutomo ${ }^{4}$ \\ ${ }^{1}$ Fakultas Kedokteran, Universitas Jenderal Soedirman Purwokerto \\ ${ }^{2}$ Bagian Biokimia Fakultas Kedokteran Universitas Gadjah Mada Yogyakarta \\ ${ }^{3}$ Bagian Penyakit Dalam Fakultas Kedokteran Universitas Gadjah Mada Yogyakarta \\ ${ }^{4}$ Bagian Penyakit Anak Fakultas Kedokteran Universitas Gadjah Mada Yogyakarta
}

\begin{abstract}
Background. Tuberculosis is one of world health problems which still needs attention. Recently, tuberculosis in Indonesia is within the biggest three after India and China. Researches reveal that albumin decreases significantly in tuberculosis patients, and which might be caused by nutrition factors (low intake, anorexia, increasing catabolism), enteropati and acute protein reaction. Low albumin is associated with an increase in IL-6 but little is known about the association between albumin and cytokines in tuberculosis. Considering albumin function of the body is very important, food survey should be done to understand what kind of food that can increase albumin in tuberculosis patients. In this survey, patients were given egg white extra. Objective. The purpose of this research was to assess the effectivity of egg white intake on albumin and IL-6 levels. Methods. A single blind randomized controlled trial was conducted at Margono Soekarjo Hospital of Purwokerto in 2013. Sampling technic used simple random sampling and 75 patients were allocated to intervention $(n=37)$ and control $(n=38)$ goups. Both groups received high energy high protein diet, the intervention group received an oral egg white-based on formula calculation Baxter for 14 days. Control group received extra soybean curd and mungbean powder. Albumin and IL-6 levels were checked before and after the study. Data were analyzed using Mann Whitney analysis to assess the differences in albumin and IL-6 levels between two groups. Results. The average of albumin level before study in the intervention group was $2.82 \mathrm{~g} / \mathrm{dL}$ and that in control group was $2.85 \mathrm{~g} /$ $d L$. Average albumin after study in the intervention group was $3.47 \mathrm{~g} / \mathrm{dL}$ and that in control group was $2.81 \mathrm{~g} / \mathrm{dL}$. Bivariat analysis showed that there was a significant difference in the increase of albumin between intervention and control groups with $p=0.001$ ( $p<0.05)$. The average of IL-6 level before study in the intervention group was $5.07 \mathrm{pg} / \mathrm{mL}$ and that in control group was $3.77 \mathrm{pg} / \mathrm{mL}$. Meanwhile, the average of albumin levels after study in the intervention and control groups were 0.006 and $2.57 \mathrm{pg} / \mathrm{mL}$, resspectively. There was a significant difference in the depletion IL-6 between those two groups with $p=0.001(p<0.05)$. Conclusion. Egg white effectively increased albumin but depleted IL-6 in tuberculosis patients.
\end{abstract}

Keywords: egg white, albumin, IL-6, tuberculosis patients.

Abstrak. Latar belakang. Tuberkulosis (TB) merupakan masalah kesehatan dunia yang masih perlu mendapat perhatian. Indonesia sampai saat ini masih menempati urutan ke 3 di dunia untuk jumlah kasus TB setelah India dan 
China dengan prevalensi 415 kasus per 100.000 penduduk pada tahun 2010 . Pasien TB mengalami penurunan kadar albumin secara bermakna, dan penyebab penurunannya diduga adalah faktor gizi (asupan makan rendah, anoreksia, peningkatan katabolisme), enteropati dan reaksi protein fase akut. Albumin yang rendah berhubungan dengan peningkatan IL-6 dan sampai saat ini masih sedikit diketahui hubungan albumin dengan sitokin inflamasi terutama IL-6. Tujuan. Penelitian ini bertujuan untuk mengkaji keefektifan putih telur terhadap peningkatan albumin dan penurunan aktivasi IL-6. Metode. Penelitian yang dilakukan dengan rancangan single blind randomized controlled trial. Teknik pengambilan sampel dengan simple random sampling sebanyak 75 pasien terdiri 37 perlakuan dan 38 kontrol. Kelompok perlakuan diberikan terapi diit Tinggi Energi Tinggi Protein standar rumah sakit dan ekstra putih telur dikukus, sesuai dengan kebutuhan albumin pasien berdasarkan perhitungan formula Baxter, diberikan selama 14 hari. Kelompok kontrol diberikan terapi diit Tinggi Energi Tinggi Protein standar rumah sakit dan ekstra makanan terdiri tahu putih dan tepung hunkwe. Kadar albumin dan IL-6 diperiksa sebelum dan setelah perlakuan. Analisis data menggunakan uji Mann Whitney untuk mengetahui perbedaan kenaikan kadar albumin kedua kelompok.. Hasil. Hasil penelitian menunjukkan rerata kadar albumin awal kelompok perlakuan adalah 2,82 g/dL dan kelompok kontrol adalah 2,85 g/dL. Kadar rerata albumin akhir pada kelompok perlakuan adalah 3,47 g/dL dan pada kelompok kontrol adalah 2,81 g/dL. Hasil analisa bivariat menunjukkan terdapat perbedaan signifikan terhadap rerata peningkatan kadar albumin pada kelompok perlakuan dan kelompok kontrol dengan $p=0,001(p<0.05)$. Hasil penelitian menunjukkan rerata IL-6 sebelum penelitian pada kelompok perlakuan 5,07 pg/mL dan kelompok kontrol 3,77 pg/mL. Rerata IL-6 setelah penelitian pada kelompok perlakuan $0.0006 \mathrm{pg} / \mathrm{mL}$ dan pada kelompok control $2,57 \mathrm{pg} / \mathrm{mL}$. Uji statistik menunjukkan perbedaan signifikan antara kelompok perlakuan dan kontrol dengan $\mathrm{p}=0.001(\mathrm{p}<0.05)$. Kesimpulan. Putih telur berdaya guna meningkatkan kadar albumin dan meghambat reaktivasi IL-6 pada pasien TB.

Kata Kunci: putih telur, albumin, IL-6, pasien tuberkulosis.

\section{PENDAHULUAN}

Tuberkulosis (TB) sampai saat ini masih menjadi masalah kesehatan dunia yang perlu mendapat perhatian. Indonesia sampai masih menempati urutan ke-3 di dunia dalam hal jumlah kasus TB setelah India dan China. Tuberkulosis di Indonesia mempunyai prevalensi 415 kasus per 100.000 penduduk pada tahun $2010^{1}$.

Pasien TB paru mengalami penurunan status gizi, hal ini tercermin dari kadar albumin dalam serum pasien dengan TB lebih rendah dibandingkan dengan subjek sehat. Selain kadar albumin, kadar transferin dalam serum juga menurun pada pasien TB ${ }^{2}$. Data ini juga didukung penelitian serupa, dimana yang menunjukkan kadar protein total pasien TB paru lebih rendah, dan rata-rata kadar albuminnya dalam serum lebih rendah dari subjek sehat ${ }^{3}$. Penelitian ini didukung penelitian lain yang menunjukkan bahwa kadar albumin dalam serum turun secara bermakna pada penderita $\mathrm{TB}$, dan penyebab penurunannya diduga adalah faktor gizi (asupan makan rendah, anoreksia, peningkatan katabolisme), enteropati dan reaksi protein fase akut ${ }^{4}$. 
Rifampisin merupakan obat TB paru. Rifampisin berikatan kuat dengan albumin pada pasien TB paru ${ }^{5}$. Bukti menunjukkan rifampisin lebih berikatan dengan albumin daripada protein lain. Selain rifampisin obat TB paru yang lain yaitu isoniasid juga berikatan kuat dengan albumin ${ }^{6}$. Ikatan yang kuat ini diharapkan efek antimikrobial OAT meningkat sehingga menurunkan sitokin inflamasi dan mempercepat penyembuhan.

Sitokin IL-1 pada TB paru akan menginduksi makrofag untuk memproduksi TNF $\alpha$. Kadar TNF $\alpha$ yang tinggi menyebabkan penurunan berat badan, penurunan sintesis albumin, dan penurunan mRNA albumin. Dalam hal ini menunjukkan bahwa TNF $\alpha$ menghambat ekspresi gen albumin. Penurunan albumin dalam serum juga diduga disebabkan kelaparan dan inflamasi akut, dimana keduaduanya menurunkan sintesis albumin ${ }^{7}$.

Pasien TB paru terjadi peningkatan produksi IL-6 sedangkan TNF $\alpha$ dan IL$1 \beta$ tidak berbeda dengan kontrol sehat. Dari hasil penelitian ini juga ditunjukkan bahwa penurunan BMI berhubungan dengan tingginya kadar TNF $\alpha$ dan IL-6. TNF $\alpha$ dan IL-6 menyebabkan anoreksia, peningkatan katabolisme jaringan lemak dan protein otot yang menimbulkan penurunan berat badan ${ }^{8}$.

Telur merupakan satu bahan pangan hewani yang mempunyai kandungan protein tinggi. Jenis telur yang biasa dikonsumsi masyarakat Indonesia adalah telur ayam ras, telur yam kampung dan telur itik. Tingkat konsumsi telur ayam ras lebih tinggi karena harganya relatif murah dan tingkat ketersediaannya tinggi di pasaran. Telur merupakan sumber albumin dari hewani. Diketahui albumin pada telur (ovalbumin) paling banyak terdapat pada putih telurnya daripada kuningnya. Putih telur ayam ras dalam setiap 100 gramnya mengandung ratarata $10,5 \mathrm{~g}$ protein yang $95 \%$ nya adalah albumin (9,83 g), sedang putih telur itik setiap $100 \mathrm{~g}$ mengandung rata-rata $11 \mathrm{~g}$ protein ${ }^{9}$.

Pemberian putih telur $15 \mathrm{~g} /$ hari pada pasien gagal ginjal terminal selama 3-6 bulan meningkatkan kadar albumin dalam serum lebih tinggi daripada hanya dengan diit konvensional. Hal ini apakah juga berlaku pada pasien TB paru, maka perlu penelitian penelitian lebih lanjut ${ }^{10}$.

Studi pendahuluan yang dilakukan pada pasien TB dengan hipoalbumin di RSUD Prof. Dr. Margono Soekarjo Purwokerto menunjukkan bahwa pemberian ekstra putih telur sesuai kebutuhan (formula Baxter) selama 10 hari dapat meningkatkan kadar albumin dalam serum dengan rata-rata 1.13 g/dL. Dengan kenaikan kadar albumin ini diharapkan bahwa pemberian ekstra putih telur pada pasien TB dapat meningkatkan efek antimikrobial OAT dan menghambat produksi sitokin inflamasi IL-6.

\section{METODE PENELITIAN}

Desain penelitian ini adalah Single Blind Randomized Controlled Trial. Subjek penelitian dibagi menjadi dua kelompok yaitu kelompok perlakuan dan kelompok kontrol. Kelompok perlakuan diberi diit standar rumah sakit ditambah ekstra putih telur ayam ras dan kelompok kontrol diberi diit standar rumah sakit ditambah tahu putih dicampur dengan tepung hunkwe yang bentuk, warna dan ukurannya sama dengan ekstra putih telur.

Populasi dalam penelitian ini adalah pasien TB paru dengan kondisi hipoalbumin yang dirawat di RSUD Prof. Dr. Margono Soekarjo Purwokerto. Sampel pasien TB paru adalah baru dengan kadar albumin darah $<3$, $5 \mathrm{~g} / \mathrm{dL}$, berusia 18-60 tahun, mendapat diit oral atau enteral dan asupan energi minimal 80\%. TB paru dengan kehamilan, pasien TB paru dengan komorbid hepatitis, komplikasi sirosis hati, sindroma nefrotik, gagal ginjal, luka bakar, gangguan lambung, penyakit usus, diabetes melitus dan kanker dan pasien yang mendapat albumin intra vena dieksklusi. Dari penelitian ini jumlah sampel diperoleh kelompok perlakuan 37 dan kelompok kontrol 38.

Pemberian ekstra putih telur yang diberikan pada masing-masing pasien perlakuan berdasarkan Rumus Formula Baxter : Penambahan Albumin : [( kadar albumin standar) - (kadar albumin saat ini)] 
x BB aktual x 0,8 (konstanta Baxter) 100 gr putih telur mengandung $10,5 \mathrm{gr}$ protein dan $95 \%$ albumin jadi tiap 100 gr putih telur mengandung 10 gr albumin. Pemberian putih telur pada kelompok perlakuan berdasarkan kebutuhan albumin pasien sebanyak 3 kali sehari (pagi, siang dan sore) selama 14 hari. Kelompok kontrol diberikan ekstra berupa campuran tahu putih dan tepung hunkwe dengan ukuran yang sama dengan kelompok perlakuan. Pengukuran kadar albumin dilakukan pada awal dan akhir penelitian kedua kelompok dengan metode bromocesol green.

Pengumpulan darah sebanyak $9 \mathrm{ml}$ diambil melalui darah vena untuk pemeriksaan darah lengkap, albumin, dan sitokin. Darah disentrifugasi selama 15 menit dengan kecepatan 1000xg pada suhu ruang. Pindahkan serum yang dihasilkan ke dalam tabung EDTA sebanyak $3 \mathrm{ml}$ dan disimpan pada suhu $-20^{\circ}$ C. Pengukuran kadar albumin dilakukan pada awal dan akhir penelitian kedua kelompok dengan metode bromocesol green. Pengukuran sitokin inflamasi menggunakan metode Quantikine HS Elisa. IL beta dengan minimal detected $0.057 \mathrm{pq} / \mathrm{mL}$.

Analisa data dilakukan baik univariat maupun bivariat. Analisa univariat dilakukan terhadap tiap variabel dari hasil penelitian dalam bentuk distribusi dan persentase dari tiap variabel. Analisa bivariat dalam penelitian ini dilakukan untuk mengetahui perbedaan peningkatan kadar albumin pada kedua kelompok dengan uji statistik Mann Whitney karena data tidak terdistribusi normal.

\section{HASIL DAN PEMBAHASAN}

\section{Karakteristik Dasar Subjek Penelitian}

Subjek penelitian sebagian besar laki-laki dengan jumlah $23(62.2 \%)$ pada kelompok perlakuan dan $25(65.8 \%)$ pada kelompok kontrol (tabel 1). Berdasarkan distribusi umur pada kelompok perlakuan terbesar pada rentang $>50-60$ tahun dan pada kelompok kontrol terbanyak pada kelompok umur $>30$ 40 tahun dan $>40-50$ tahun sebanyak $36.8 \%$. Tingkat pendidikan subjek penelitian paling banyak pendidikan dasar sebanyak $75.7 \%$ pada kelompok perlakuan dan $63.1 \%$ pada kelompok kontrol. Pekerjaan subjek penelitian pada kedua kelompok paling besar adalah swasta dengan kelompok perlakuan sebesar $59.5 \%$ dan kelompok kontrol sebesar $84.2 \%$. Indeks massa tubuh pada kedua kelompok terbesar dengan status gizi normal yaitu 63\% pada kelompok perlakuan dan $81.6 \%$ pada kelompok kontrol (Tabel 1).

Tabel 1. Jenis kelamin, umur, pendidikan, pekerjaan dan IMT subjek penelitian

\begin{tabular}{|c|c|c|c|c|c|c|}
\hline \multicolumn{2}{|c|}{ Karakteristik } & \multicolumn{2}{|c|}{ Perlakuan } & \multicolumn{2}{|c|}{ Kontrol } & \multirow[t]{2}{*}{$\mathbf{P}$} \\
\hline & & $\mathbf{N}$ & $(\%)$ & $\mathbf{N}$ & $(\%)$ & \\
\hline \multirow[t]{2}{*}{ Jenis kelamin } & Laki-laki & 23 & $62.2 \%$ & 25 & $65.8 \%$ & 0.97 \\
\hline & Perempuan & 14 & $37.8 \%$ & 13 & $34.2 \%$ & \\
\hline \multirow[t]{4}{*}{ Umur } & 18-30 tahun & 11 & $29.8 \%$ & 8 & $21 \%$ & 0.11 \\
\hline & $>30-40$ tahun & 7 & $18.9 \%$ & 14 & $36.8 \%$ & \\
\hline & $>40-50$ tahun & 7 & $18.9 \%$ & 14 & $36.8 \%$ & \\
\hline & $>50-60$ tahun & 12 & $32.4 \%$ & 2 & $5.3 \%$ & \\
\hline \multirow[t]{3}{*}{ Pendidikan } & Dasar & 28 & $75.7 \%$ & 24 & $63.1 \%$ & 0.43 \\
\hline & Menengah & 7 & $18.9 \%$ & 12 & $31.6 \%$ & \\
\hline & Sarjana & 2 & $5.4 \%$ & 2 & $5.3 \%$ & \\
\hline \multirow[t]{2}{*}{ Pekerjaan } & PNS & 1 & $2.7 \%$ & 1 & $2.6 \%$ & 0.21 \\
\hline & Swasta & 22 & $59.5 \%$ & 32 & $84.2 \%$ & \\
\hline
\end{tabular}




\begin{tabular}{|c|c|c|c|c|c|c|}
\hline \multicolumn{2}{|c|}{ Karakteristik } & \multicolumn{2}{|c|}{ Perlakuan } & \multicolumn{2}{|c|}{ Kontrol } & \multirow[t]{2}{*}{$\mathbf{P}$} \\
\hline & Ibu Rumah Tangga & 14 & $37.8 \%$ & 5 & $13.2 \%$ & \\
\hline \multirow[t]{3}{*}{ IMT } & Underweight & 10 & $27 \%$ & 7 & $18,4 \%$ & 0.40 \\
\hline & Normal & 27 & $63 \%$ & 31 & $81,6 \%$ & \\
\hline & h Subjek & 37 & $100 \%$ & 38 & $100 \%$ & \\
\hline
\end{tabular}

\section{Kadar Albumin}

Uji normalitas data menggunakan Shapiro-Wilk diperoleh sebaran data tidak terdistribusi normal pada kadar albumin pra dan pasca intervensi. Transformasi data dengan $\log 10$ juga diperoleh sebaran data yang tidak normal, maka uji statistik yang digunakan adalah uji non parametrik Mann Whitney test.

Penelitian ini berangkat dari pasien dengan hipoalbumin pada kedua kelompok. Hasil uji statistik menunjukkan kadar albumin pra penelitian pada kedua kelompok tidak berbeda dengan $p>0.05$ (Tabel 2).

Tabel 2. Kadar albumin awal

\begin{tabular}{ccc}
\hline Kadar & Perlakuan & Kontrol \\
\cline { 2 - 3 } Albumin & Rerata \pm SD & Rerata \pm SD \\
\hline Albumin & $2.85 \pm 0.38$ & $2.83 \pm 0.40$ \\
\hline
\end{tabular}

Kadar albumin terendah pra intervensi pada kelompok perlakuan adalah $2.04 \mathrm{~g} / \mathrm{dL}$, sedangkan kadar albumin tertinggi adalah $3.44 \mathrm{~g} / \mathrm{dL}$. Kadar albumin pasca intervensi pada kelompok perlakuan terendah adalah $2.65 \mathrm{~g} / \mathrm{dL}$ dan tertinggi adalah $5.6 \mathrm{~g} / \mathrm{dL}$. Rerata kadar albumin awal pada kelompok perlakuan sebesar $2.85 \pm 0.38 \mathrm{~g} / \mathrm{dL}$ dan rerata kadar albumin setelah intervensi adalah $3.56 \pm$ $0.53 \mathrm{~g} / \mathrm{dL}$ (tabel 4). Uji normalitas data kadar albumin pada kelompok perlakuan pra maupun pasca menunjukkan tidak berdistribusi normal, setelah dilakukan transform data dengan log 10 hasilnya juga menunjukkan data tidak terdistribusi normal sehingga uji statistik yang digunakan adalah Mann Whitney dengan $\mathrm{p}<0.05$. Hasil penelitian ini menunjukkan ada perbedaan kadar albumin pre dan post perlakuan, dimana kadar albumin setelah perlakuan mengalami kenaikan dengan rerata $0.70 \pm 0.52 \mathrm{~g} / \mathrm{dL}$.

Kadar albumin terendah sebelum intervensi pada kelompok perlakuan adalah $2.04 \mathrm{~g} / \mathrm{dL}$ sedangkan kadar albumin tertinggi adalah $3.44 \mathrm{~g} / \mathrm{dL}$. Kadar albumin setelah intervensi pada kelompok perlakuan terendah adalah $2.65 \mathrm{~g} / \mathrm{dL}$ dan tertinggi adalah $5.6 \mathrm{~g} /$ dL. Rerata kadar albumin awal pada kelompok perlakuan sebesar $2.85 \mathrm{~g} / \mathrm{dL}$ dan rerata kadar albumin setelah intervensi adalah $3.56 \mathrm{~g} / \mathrm{dL}$.

Kadar albumin terendah sebelum intervensi pada kelompok kontrol adalah $1.76 \mathrm{~g} / \mathrm{dL}$ sedangkan kadar albumin tertinggi adalah $3.49 \mathrm{~g} / \mathrm{dL}$. Kadar albumin setelah intervensi pada kelompok kontrol terendah adalah $1.73 \mathrm{~g} / \mathrm{dL}$ dan tertinggi adalah $4.21 \mathrm{~g} /$ dL. Rerata kadar albumin awal pada kelompok kontrol sebesar $2.83 \mathrm{~g} / \mathrm{dL}$ dan rerata kadar albumin akhir adalah $2.71 \mathrm{~g} / \mathrm{dL}$. Kelompok kontrol terdapat 7 (18.4\%) subjek penelitian yang kadar albuminnya meningkat. Kenaikan kadar albumin pada kelompok kontrol diduga dipengaruhi status gizi, pada kelompok kontrol yang mengalami kenaikan kadar albumin memiliki status gizi baik.

Kenaikan kadar albumin pada kelompok perlakuan dengan rerata sebesar $0.70 \mathrm{~g} / \mathrm{dL}$. Kelompok perlakuan semua subjek penelitian mengalami kenaikan kadar albumin. Penurunan kadar albumin pada kelompok kontrol dengan rerata sebesar $-0.12 \mathrm{~g} / \mathrm{dL}$. Hasil uji statistik didapatkan $\mathrm{p}=0.001(\mathrm{p}<0.05)$ maka didapatkan adanya perbedaan signifikan antara kadar serum albumin sebelum dan sesudah pemberian putih telur pada kelompok perlkuan dan kelompok control (Tabel 3). Putih telur terbukti efektif untuk meningkatkan kadar albumin pada pasien Tuberkulosis dengan hipoalbumin. 
Tabel 3. Pengaruh pemberian ekstra putih telur terhadap kadar albumin

\begin{tabular}{cccc}
\hline \multicolumn{1}{c}{$\begin{array}{c}\text { Kadar } \\
\text { Albumin }\end{array}$} & Perlakuan & Kontrol & \multirow{2}{*}{ p } \\
\cline { 2 - 3 } $\begin{array}{l}\text { Selisih kadar } \\
\text { albumin }\end{array}$ & $0.70 \pm 0.52$ & $-0.12 \pm 0.31$ & $0.001^{*}$ \\
\hline
\end{tabular}

Putih telur merupakan protein dengan nilai bilogi tinggi (100) sehingga seluruh protein putih telur dapat diserap tubuh. Perbandingan antara nitrogen ditahan dan nitrogen dikonsumsi merupakan paling tinggi diantara protein makanan (Net Protein Utilization sebesar 94) ${ }^{15}$.

Kandungan protein akan meningkat untuk setiap 1 gram berat telur. Putih telur mengandung albumin sebanyak 95\% dalam bentuk ovoalbumin $54 \%$, ovamukoid $11 \%$, lisosim 11,5\%, ovomukoin 1,5\%avidin $0,05 \%$ dan ovoglobulin $0,5 \%{ }^{16}$. Ovalbumin merupakan jenis albumin yang paling mudah diserap oleh usus dibanding jenis albumin lain. ${ }^{17}$.

Putih telur dipecah pada sepanjang saluran pencernaan menjadi ploippeptida kecil yang diserap oleh usus kemudian ditranspor menuju hati, menggalami proses deaminasi dan dihidrolisis menjadi asam amino oleh enzim transaminase. Enzim peptidase, aminopeptidase dan karboksipeptidase memecah asam amino menjadi alfa alanin yang bergabung dengan glisin membentuk fraksi nitrogen amino dan ikatan sulfide. Sebagian asam amino bebas berikatan dengan nitrogen fraksi amino yang masuk sistem sekretorik (membrane endoplasma kasar, membran endoplasma halus, dan apparatus golgi) dan albumin disekresi oleh vesikel sekretorik, melalui transport aktif masuk sistem peredaran darah ${ }^{18}$.

\section{Sitokin Inflamasi IL-6}

\begin{tabular}{lccc}
\hline \multirow{2}{*}{$\begin{array}{c}\text { Kadar } \\
\text { Albumin }\end{array}$} & $\begin{array}{c}\text { Perlakuan } \\
(\mathbf{p g} / \mathbf{m L})\end{array}$ & $\begin{array}{c}\text { Kontrol }(\mathbf{p g} / \\
\mathbf{m L})\end{array}$ & $\mathbf{p}$ \\
\cline { 2 - 3 } & Rerata \pm SD & Rerata \pm SD & \\
\hline Selisih & $-0.39 \pm 1.98$ & $0.76 \pm 3.21$ & $0.001^{*}$ \\
IL-6 & & & \\
\hline \multicolumn{2}{c}{ Hasil penelitian kadar sitokin inflamasi }
\end{tabular}

IL-6, pada kelompok perlakuan data pra dan pasca menunjukkan penurunan, namun secara statistik tidak terdapat perbedaan dengan $\mathrm{p}>0.05$. Pada kelompok kontrol terdapat peningkatan kadar sitokin inflamasi antara data pra dan pasca penelitian dan secara statistik terdapat perbedaan dengan $\mathrm{p}<0.05$ (tabel 4)

Tabel 4. Pengaruh pemberian ekstra putih telur terhadap kadar IL-6

\begin{tabular}{|c|c|c|c|}
\hline Sitokin & Pre $(\mathrm{pg} / \mathrm{mL})$ & Post (pg/mL) & \\
\hline Inflamasi & Rerata \pm SD & Rerata \pm SD & \\
\hline $\begin{array}{l}\text { IL-6 } \\
\text { Perlakuan }\end{array}$ & $0.90 \pm 1.45$ & $0.50 \pm 1.42$ & 0.06 \\
\hline IL-6 Kontrol & $0.67 \pm 1.62$ & $1.46 \pm 2.71$ & $0.02 *$ \\
\hline
\end{tabular}

Hasil penelitian menunjukkan selisih kadar sitokin inflamasi IL-6 pada kelompok perlakuan terdapat penurunan sebesar $-0.39 \pm 1.98 \mathrm{pg} / \mathrm{mL}$, pada kelompok kontrol terdapat peningkatan sebesar $0.76 \pm 3.21$ $\mathrm{pg} / \mathrm{mL}$. penelitian ini menunujukkan pada kelompok perlakuan jelas terjadi penurunan IL-6. Hasil uji statistik dengan Mann Whitney untuk menguji perbedaan kelompok perlakuan dan kontrol menunjukkan terdapat perbedaan dengan $\mathrm{p}<0.05$ (tabel 5)

Tabel 5. Pengaruh pemberian ekstra putih telur terhadap selisih kadar IL-6

\begin{tabular}{cccc}
\hline \multirow{2}{*}{$\begin{array}{c}\text { Kadar } \\
\text { Albumin }\end{array}$} & $\begin{array}{c}\text { Perlakuan } \\
(\mathbf{p g} / \mathbf{m L})\end{array}$ & $\begin{array}{c}\text { Kontrol }(\mathbf{p g} / \\
\mathbf{m L})\end{array}$ & \multirow{2}{*}{$\mathbf{p}$} \\
\cline { 2 - 3 } & Rerata \pm SD & Rerata \pm SD & \\
\hline Selisih IL-6 & $-0.39 \pm 1.98$ & $0.76 \pm 3.21$ & $0.001^{*}$ \\
\hline
\end{tabular}

Kadar albumin yang rendah pada pasien TB disebabkan anoreksia, malnutrition dan malabsorbsi. Albumin juga merupakan protein fase akut negatif yang jumlah akan menurun pada saat infeksi, luka atau stress. Penurunan albumin ini merupakan hasil peningkatan kebutuhan metabolisme untuk perbaikan jaringan dan netralisasi radikal bebas. Radikal bebas menyerang membran sel menyebabkan kerusakan jaringan dan menyisakan penyakit TB. Peningkatan asupan makan pada penderita 
TB akan meningkatkan kadar albumin ${ }^{19}$ Albumin adalah antioksidan penting didalam serum yang berperan utama mengikat asam lemak bebas, kation divalens dan hydrogen oxochloride (HOCI). Peran albumin sebagai antioksidan ini yang diduga dapat menghambat kerusakan jaringan sehingga sitokin inflamasi IL-6 pada kelompok perlakuan mengalami penurunan ${ }^{20}$.

Albumin mempunyai peranan penting sebagai pengangkut bahan kimia tertentu termasuk obat-obatan melalui sistem sirkulasi, pengangkut berbagai materi yang tak larut dalam air (bilirubin, asam lemak, dan beberapa macam hormon), menjaga tekanan onkotik plasma, sebagai pertahanan tubuh (fungsi kontrol dan antioksidan), membantu metabolisme zat gizi dan mempercepat pemulihan jaringan sel. Peningkatan albumin padakelompok perlakuan diduga mempercepat proses pemulihan jaringan yang rusak karena infeksi TB sehingga sitokin infllamasi IL-6 menurun ${ }^{21}$.

Fungsi albumin lain adalah sebagai cadangan air untuk tubuh, mencegah mengerut dan tersumbatnya pembuluh darah, membantu mempertahankan tekanan tekanan osmotik, sebagai media transport (sejumlah obat termasuk sulfamida, penisilin, rifampisin dan isoniasid), sebagai perlindungan tubuh melawan benda-benda asing (virus, bakteri, jamur dan sel-sel kanker). Peningkatan albumin pada kelompok perlakuan setelah mendapat ekstra putih telur akan meningkatkan daya transport obat-obat TB. Peningkatan daya transport obat-obat TB akan mempercepat proses pemulihan jaringan paru yang rusak sehingga sitokin inflamasi seperti IL-6 menurun ${ }^{22}$.

Albumin juga berfungsi sebagai perlindungan tubuh dengan mengikat racun bersama bilirubin dibawa ke hepar dan menetralkannya. Bilirubin yang berikatan dengan albumin bertindak sebagai antioksidan dengan mencegah kerusakan vitamin $\mathrm{E}$ oleh radikal bebas. Albumin juga sebagai alat transpor obat seperti rifampisin yang merupakan obat terapi TB. Albumin merupakan protein plasma dan obat TB berikatan dengan protein plasma. Obat anti TB dimetabolisme di hepar dan diekskresikan bersama bilirirubin oleh empedu ${ }^{23}$.

\section{KESIMPULAN}

Berdasarkan hasil penelitian diatas menunjukkan putih telur efektif meningkatkan kadar albumin dan menurunkan sitokin inflamasi IL-6. Putih telur dapat digunakan sebagai bagian dari terapi untuk meningkatkan kadar serum albumin dan menghambat inflamasi penderita TB dengan hipoalbumin.

\section{DAFTAR PUSTAKA}

Pichard, C., Ursula, G. K., Alfredo, M., Arnaud, P., Bernard, V., and Pierre, U. 2004. an increased length of stay. American Journal of Clinical Nutrition. 79:613-8. Nutritional assessment: lean body mass depletion at hospital admission is associated with increased lengt of stayamrican journal of Clinical Nutrition. 79: 613-8

Banga, A., and Khilnani. 2007. Serial Estimations of Serum Albumin Levels in Critically Ill Patients. The Journal of The American Association. 132: 4-6.

Espinoza, G.L., Chavez, J.G., Martín, F.,1 Martínez, H.R.,Laura Cortés-Sanabria, Enrique, R.C., Alfonso, M. 2005. Randomized, Open label, Controlled Clinical Trial of Oral Administration of an Egg Albumin-Based Protein Suplement to Patients on Continous Ambulatory Peritoneal Dialysis. Peritoneal Dialysis International. 25:173-180

Boirie, Y., Gachon, P., Cordat, N., Ritz, P., and Beaufre, B. 2001. Differential Insulin Sensitivities of Glucose, Amino Acid, and Albumin Metabolism in Elderly Men and Women. The Journal of Clinical Endocrinology \& Metabolism. . 86:638-44

Saryono., Prastowo, A., and Mekar, D. 2006. Perbedaan Kadar Albumin Plasma pada Pasien 
Sebelum dan Sesudah Menjalani Rawat Inap di RSUD Margono Soekardjo. The Soedirman Journal of Nursing. 1: 1-5.

Lassen, KO., Jens, O., Edvin, G., Filip, K., dan Merete, B. 2006. Nutritional Care of Medical in Patients: A Health Technology Assessment. Biomedical Central Journal. 1086: 6963-7.

Pichard, C., Ursula, G. K., Alfredo, M., Arnaud, P., Bernard, V., and Pierre, U. 2004. Nutritional assessment: lean body mass depletion at hospital admission is associated with an increased length of stay. American Journal of Clinical Nutrition. 79:613-8.

Mercer, T., Craig, A. J., Kevin, E., Yarasheski., Nadine, S.,Wayne, W., C.Anna, E. 2007. Nutrient Ingestion, Protein Intake, and Sex, but Not Age, Affect the Albumin Synthesis Rate in Humans. American Society for Nutrition. 134:1734-40.

PERSAGI., 2008. Tabel Komposisi Pangan Indonesia. Elex Media Komputindo. Jakarta. Edisi 1. p42

Almatsier, S. 2000. Prinsip Dasar ilmu Nutrisi: Nutisi Beda. Gramedia, Jakarta. Hal:67-9.

Soelarto, D S. 1997. Analisis Nutrisi dan Keuntungan pada Berbagai Pembuatan Telur Ditinjau dari Kandungan Proteinnya. Karya Tulis Ilmiah. FK UGM, Yogyakarta. (Tidak dipublikasikan).

Petitte, J.M., and Mozdziak, P. E. 2007. The Incredible, Edible, and Therapeutic Egg. The National Academy of Sciences of the United State of America. 104: 739-1740.

Kim, J. K., Matsukawa, Y.,Yamahara, H., Kalra, V. K., Vincenth , H. L. Lee and Crandalli, E. D. 2003. Absorption of Intact Albumin Across Rat Alveolar Epithelial Cell Monolayers. American Journal Physiology. 284: L458-L465.

Ai ly et al., (14)

Negatif oxochloride (HOCI) (15)

Pichard, C., Ursula, G. K., Alfredo, M., Arnaud, P., Bernard, V., and Pierre, U. 2004. an increased length of stay. American Journal of Clinical Nutrition. 79:613-8. Nutritional assessment: lean body mass depletion at hospital admission is associated with increased lengt of stayamrican journal of Clinical Nutrition. 79: 613-8

Banga, A., and Khilnani. 2007. Serial Estimations of Serum Albumin Levels in Critically Ill Patients. The Journal of The American Association. 132: 4-6.

Espinoza, G.L., Chavez, J.G., Martín, F.,,1 Martínez, H.R.,Laura Cortés-Sanabria, Enrique, R.C., Alfonso, M. 2005. Randomized, Open label, Controlled Clinical Trial of Oral Administration of an Egg Albumin-Based Protein Suplement to Patients on Continous Ambulatory Peritoneal Dialysis. Peritoneal Dialysis International. 25:173-180

Boirie, Y., Gachon, P., Cordat, N., Ritz, P., and Beaufre, B. 2001. Differential Insulin Sensitivities of Glucose, Amino Acid, and Albumin Metabolism in Elderly Men and Women. The Journal of Clinical Endocrinology \& Metabolism. . 86:638-44

Saryono., Prastowo, A., and Mekar, D. 2006. Perbedaan Kadar Albumin Plasma pada Pasien Sebelum dan Sesudah Menjalani Rawat Inap di RSUD Margono Soekardjo. The Soedirman Journal of Nursing. 1: 1-5.

Lassen, KO., Jens, O., Edvin, G., Filip, K., dan Merete, B. 2006. Nutritional Care of Medical in Patients: A Health Technology Assessment. Biomedical Central Journal. 1086: 6963-7.

Pichard, C., Ursula, G. K., Alfredo, M., Arnaud, P., Bernard, V., and Pierre, U. 2004. Nutritional 
assessment: lean body mass depletion at hospital admission is associated with an increased length of stay. American Journal of Clinical Nutrition. 79:613-8.

Mercer, T., Craig, A. J., Kevin, E., Yarasheski., Nadine, S.,Wayne, W., C.Anna, E. 2007. Nutrient Ingestion, Protein Intake, and Sex, but Not Age, Affect the Albumin Synthesis Rate in Humans. American Society for Nutrition. 134:1734-40.

Almatsier, S. 2000. Prinsip Dasar ilmu Nutrisi: Nutisi Beda. Gramedia, Jakarta. Hal:67-9.

Soelarto, D S. 1997. Analisis Nutrisi dan Keuntungan pada Berbagai Pembuatan Telur Ditinjau dari Kandungan Proteinnya. Karya Tulis Ilmiah. FK UGM, Yogyakarta. (Tidak dipublikasikan).

Petitte, J.M., and Mozdziak, P. E. 2007. The Incredible, Edible, and Therapeutic Egg. The National Academy of Sciences of the United State of America. 104: 739-1740.Kim, J. K., Matsukawa, Y., Yamahara, H., Kalra, V. K., Vincenth , H. L. Lee and Crandalli, E. D. 2003. Absorption of Intact Albumin Across Rat Alveolar Epithelial Cell Monolayers. American Journal Physiology. 284: L458-L465. 